\title{
Changes in tropospheric ozone levels over the Three Representative Regions of China observed from space by the Tropospheric Emission Spectrometer (TES), 2005-2010
}

\author{
SHEN LuLu \& WANG YuXuan* \\ Ministry of Education Key Laboratory for Earth System Modeling, Center for Earth System Science, Institute for Global Change Studies, \\ Tsinghua University, Beijing 100084, China
}

Received December 15, 2011; accepted February 16, 2012; published online April 24, 2012

\begin{abstract}
Tropospheric ozone observations over China from 2005 to 2010 at three pressure levels (484, 681 and $825 \mathrm{hPa}$ ) from the Tropospheric Emission Spectrometer on board the NASA Aura satellite have been analyzed. Fourier Transform analysis revealed the trends and seasonality of regionally-averaged, monthly-mean ozone concentrations over western, northern and southern China. Significant increases in ozone levels are found over all three regions at $464 \mathrm{hPa}$ and the rate of increase is fastest over northern China, reaching $0.89 \pm 0.059 \mathrm{~nL} /(\mathrm{L}$ a). At $681 \mathrm{hPa}$, ozone shows increases over northern and western China, at a rate of $0.57 \pm$ $0.065 \mathrm{~nL} /(\mathrm{L}$ a) and $0.41 \pm 0.041 \mathrm{~nL} /(\mathrm{L}$ a) respectively, but is constant over southern China. At $825 \mathrm{hPa}$, ozone increases at a rate of $0.36 \pm 0.074 \mathrm{~nL} /(\mathrm{L}$ a) over northern China, while decreasing over southern China at a rate of $-0.21 \pm 0.061 \mathrm{~nL} /(\mathrm{L}$ a). Over the three regions, ozone levels are generally higher in summer and lower in winter. Over southern China at all three pressure levels and northern China at the $825 \mathrm{hPa}$ level, ozone shows double peaks occurring in spring and autumn as a result of the combined effects of atmospheric chemistry and global transport. This work provides a useful observational dataset and tools for future analysis of changes in tropospheric ozone over China.
\end{abstract}

TES, ozone, China, interannual variation, seasonal variation

Citation: Shen L L, Wang Y X. Changes in tropospheric ozone levels over the Three Representative Regions of China observed from space by the Tropospheric Emission Spectrometer (TES), 2005-2010. Chin Sci Bull, 2012, 57: 2865-2871, doi: 10.1007/s11434-012-5099-x

Ozone is an important greenhouse gas and major precursor of the hydroxyl radical $(\mathrm{OH})$ in the troposphere. Surface ozone is a pollutant, with adverse impacts on human health and vegetation. Ozone precursors include $\mathrm{NO}_{x}$, VOCs, and CO. Compared with other gas pollutants, ozone has a relatively long lifetime (1-2 weeks in summer and 1-2 months in winter) [1], making it subject to long-range transport. Accordingly, ozone has been considered as a global pollutant, and much attention has been paid to temporal and spatial variability of tropospheric ozone, long-range transport of ozone and its precursors at both continental and hemispheric scales, and the effect of ozone on regional and global climate [2-4].

*Corresponding author (email: yxw@tsinghua.edu.cn)
It has been suggested that tropospheric ozone concentrations have increased significantly since the Industrial Revolution, especially in the Northern Hemisphere [5]. China's rapid economic growth in recent years has resulted in fast increasing emissions of ozone precursors $\left(\mathrm{NO}_{x}\right.$, VOCs and CO). Richter et al. [6] indicated that $\mathrm{NO}_{2}$ emissions from China have increased by 50\% between 1996 and 2003 based on remote sensing data derived from GOME and SCIAMACHY satellite instruments. This is much higher than that suggested by the bottom-up inventory [7]. By analyzing the Measurement of Ozone and Water Vapor by Airbus In-Service Aircraft (MOZAIC) flight data, Ding et al. [8] found that tropospheric ozone in eastern China has increased at an annual rate of $2 \%$ during the past 10 years. Wang et al. [9] indicated that background ozone in southern 
China has increased at a rate of $0.58 \mathrm{~nL} /(\mathrm{L}$ a), based on Hong Kong surface observations from 1994 to 2007.

Since the 1980s, China has built a few continuous surface observation stations, such as those at Shangdianzi, Linan, Longfengshan and Waliguan. These generate basic data about surface ozone concentrations and seasonal variations of the different regions [10-13]. However, compared to developed countries, ozone observations in China are very limited. Satellite remote sensing of atmospheric composition is a useful complement to surface observations. Several satellite instruments are capable of providing openaccess, quantitative information on atmospheric concentrations of ozone and its precursors, including the OMI (Ozone Monitoring Instrument) and the TES (Tropospheric Emission Spectrometer) $[14,15]$. The TES can provide vertical ozone distributions of $\mathrm{O}_{3}$ and $\mathrm{CO}$ simultaneously. Since its launch in 2004, the TES has accumulated a large amount of data applicable to the relationships between ozone and precursors, as well as the intercontinental transport of ozone [7].

In this study, we examine the change in tropospheric ozone over China from 2005 to 2010 using TES generated ozone retrieval products.

\section{Data and methodology}

\subsection{Introduction to TES data}

TES is a Fourier transform infrared emission spectrometer covering the spectral range $650-2050 \mathrm{~cm}^{-1}(3.3-15.4 \mu \mathrm{m})$ at a spectral resolution of $0.1 \mathrm{~cm}^{-1}$ (nadir viewing) or 0.025 $\mathrm{cm}^{-1}$ [16] (limb viewing). The infrared emission and absorption of the atmospheric substances closely relate to the cloud cover, pollutant concentration, pressure, temperature and other factors. Therefore, TES is able to retrieve the vertical profile of species concentrations on the basis of the emission and absorption spectrum. The method used by TES to retrieve tropospheric profiles of ozone and CO [17] has been optimized. The retrieved profile may be expressed as a linear combination of the true profile and the a priori profile weighted by the averaging kernel matrix. Ozone data provided by TES usually covers a wide range from 0-32 km in altitude, including the whole troposphere and the lower part of the stratosphere. In the lower part of troposphere, there are 1-2 degrees of freedom in the inversion method used, indicating the capability of TES to observe the vertical distribution of ozone [18].

The official TES website provides open access to the retrieval products of tropospheric ozone (http://tes.jpl.nasa. gov/). This study uses the level 3 retrieval data from Sep 2004 to Dec 2010, at 3 different elevations (825, 681 and $464 \mathrm{hPa}$ ). As an example, Figure 1 shows the global distribution of ozone at $681 \mathrm{hPa}$ in July 2009 retrieved by TES.

\subsection{Methodology}

The Fast Fourier transform (FFT) methodology is used to decompose the time-series into the sum of different sine and cosine functions with different amplitudes and frequencies. By filtering and the Inverse Fast Fourier Transform (IFFT), information is obtained in the desired frequency ranges. Fourier transform is widely applied in the study of inter-annual change and seasonal variations $[19,20]$. We define the inter-annual trend as periods longer than 1.4 years with seasonal variation less than 1.3 years. The sample frequency in this study is $12 \mathrm{~Hz}$, i.e. 1 year. A frequency of 2 $\mathrm{Hz}$ is 6 months, $3 \mathrm{~Hz} 4$ months, etc.

\section{Data summary}

The TES ozone time-series data is from Sep 2009 to Dec 2010 at three different pressure levels $(825,681$ and 464 $\mathrm{hPa}$ ) (Figure 2). On the TES website, China is divided into 3 geographical regions: western, northern and southern China. Due to the high elevation of western China, the TES data there at $825 \mathrm{hPa}$ is scarce, so this is not included in this study. Over western and northern China, ozone mixing ratios have summer maxima and winter minima. Over southern China, however, they are higher in winter and lower in summer. At 681 and $825 \mathrm{hPa}$ pressure levels, ozone over southern China shows double peaks occurring in spring and autumn. The inter-annual trend is discussed below.

As summarized in Table 1, the average ozone mixing ratio is higher over northern China than over southern China. Ozone mixing ratios increase with altitude, partly resulting from the downward transport of stratospheric ozone.

\section{Regional analysis}

Due to the significant differences between the different parts of China, the temporal variability of ozone is split by region.

\subsection{Northern China}

Figure 3 shows the frequency spectrum of ozone over

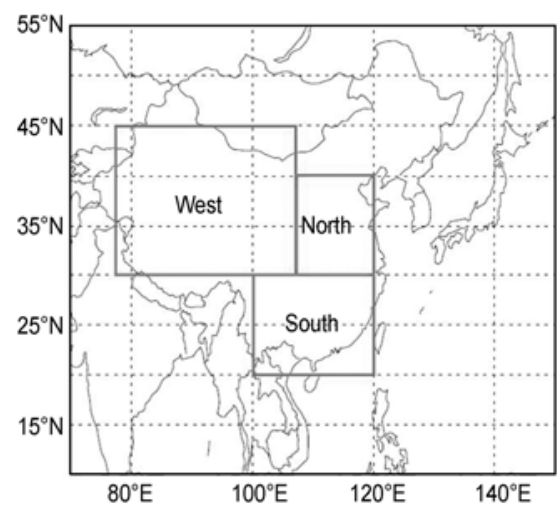

Figure 1 The three geographic regions of China adopted by TES. (http://tes.jpl.nasa.gov/visualization/SCIENCE_PLOTS/Trends/world_map _clickable.html, read 2011/10/9). 

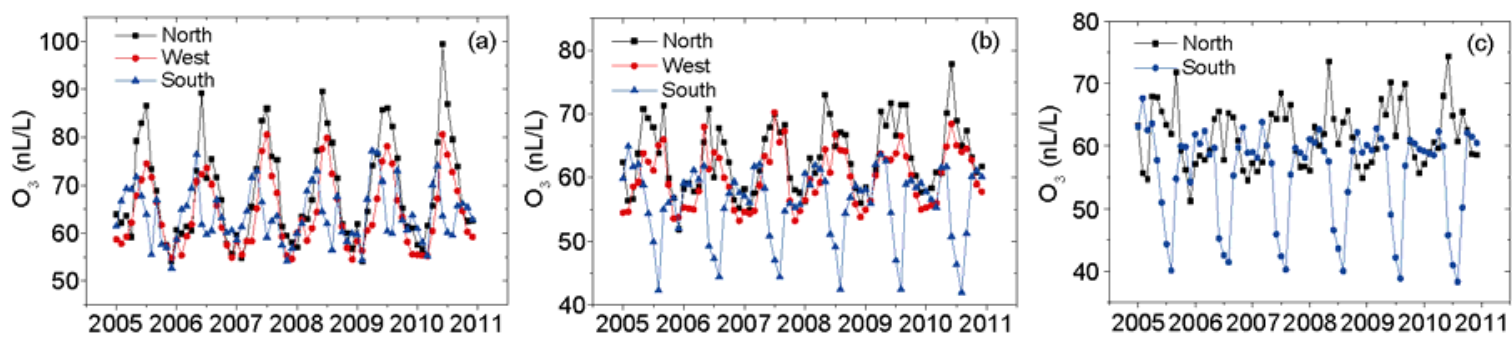

Figure 2 Ozone mixing ratios at $464 \mathrm{hPa}$ (a), $681 \mathrm{hPa}$ (b) and $825 \mathrm{hPa}$ (c) pressure levels retrieved from the TES between 2005 and 2010 over western China (red), northern China (black), and southern China (blue).
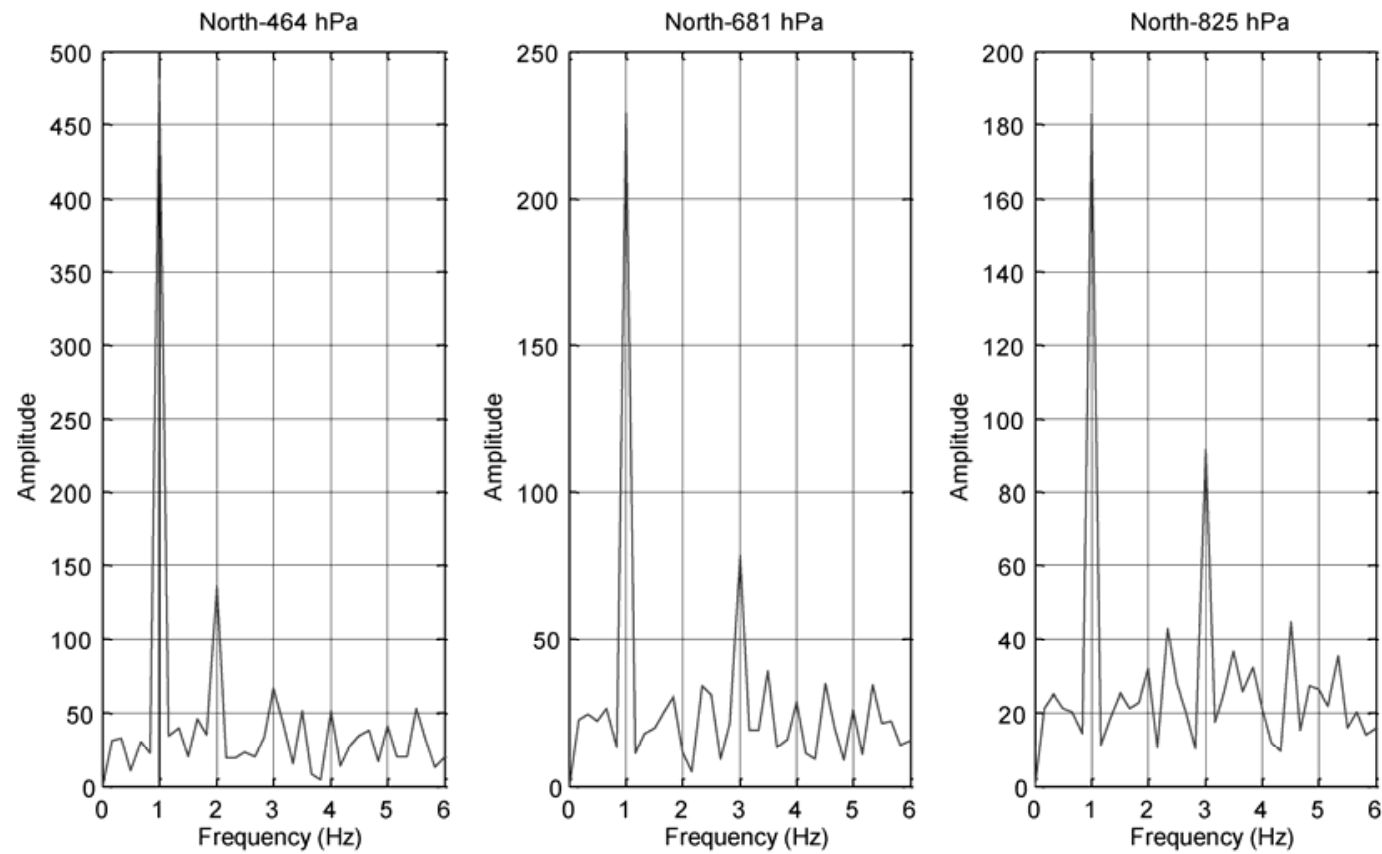

Figure 3 Frequency spectra of ozone over northern China at different pressure levels.

Table 1 TES-retrieved average ozone mixing ratios over the three Chinese regions at different pressure levels

\begin{tabular}{llll}
\hline & $464 \mathrm{hPa}$ & $681 \mathrm{hPa}$ & $825 \mathrm{hPa}$ \\
\hline North China & 68.8 & 63.1 & 61.5 \\
South China & 63.7 & 55.9 & 55.5 \\
West China & 64.1 & 60.0 & missing
\end{tabular}

northern China. A significant signal appears at $f=1 \mathrm{~Hz}$ at all pressure levels, which implies a constant seasonal variation throughout the troposphere. Another relatively strong signal appears at $f=2 \mathrm{~Hz}$ at $464 \mathrm{hPa}$, and $f=3 \mathrm{~Hz}$ at $681 \mathrm{hPa}$ and $825 \mathrm{hPa}$.

The inter-annual trend of ozone is derived by performing IFFT on the $0-0.7 \mathrm{~Hz}$ part of the spectrum, (Figure 4). A significant increasing trend of ozone mixing ratios is observed at all three pressure levels, with the largest rate of increase at $464 \mathrm{hPa}(0.89 \pm 0.059 \mathrm{~nL} /(\mathrm{L}$ a) $)$, followed by that at $681 \mathrm{hPa}(0.57 \pm 0.065 \mathrm{~nL} /(\mathrm{L} \mathrm{a}))$ and the smallest rate

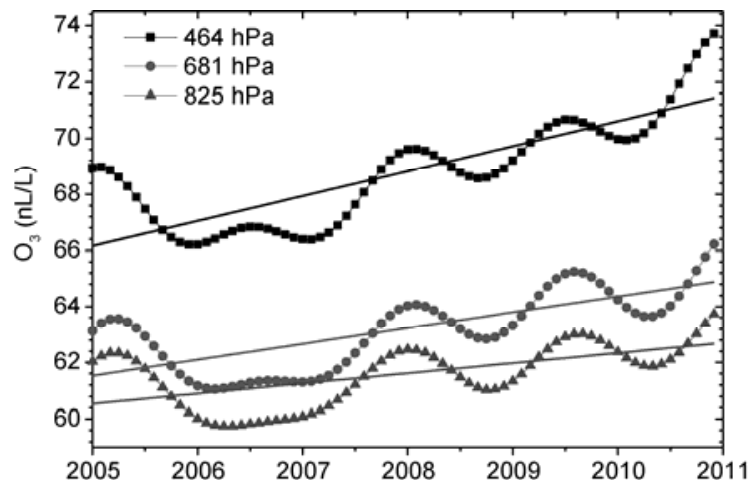

Figure 4 Inter-annual ozone trend in northern China.

at $825 \mathrm{hPa}(0.36 \pm 0.074 \mathrm{~nL} /(\mathrm{L}$ a $))$. Higher levels are more likely to be affected by the global $\mathrm{O}_{3}$ background and this trend also implies a fast increase of global background ozone. Surface ozone in Beijing is increasing at the rate1.1 $\mathrm{nL} /(\mathrm{L}$ a) from 2001 to 2006 by analyzing the observation 
data in 6 stations cites [21]. This increase is higher than that from our results, and implies three possible explanations. First, our study covers a time span from 2005 to 2010, which is different from Tang's. Second, we focus on the average ozone over whole North China instead of some big cities. Third, the TES data reflects the ozone change in the lower troposphere instead of the surface atmosphere.

From the frequency spectrogram the seasonal variation is superimposed with other different cycles. If the data is filtered such that signals with amplitudes $<15 \%$ of the maximum amplitude are excluded, and IFFT is performed in frequency ranges including $0.8-1.2,0.8-2.2$ and $0.8-3.2 \mathrm{~Hz}$, the resulting seasonal variations obtained from IFFT get much closer to the observed variations (Figure 5). The amplitude is largest at $464 \mathrm{hPa}$, reaching -13 to $15 \mathrm{~nL} / \mathrm{L}$. A weak double-peak phenomenon is observed at $825 \mathrm{hPa}$, with peaks in spring and autumn and troughs in winter and summer.

\subsection{Southern China}

The results of a similar analysis for southern China appears in Figure 6. Strong signals appear at $f=1,2$ and $3 \mathrm{~Hz}$ at all the pressure levels, with strongest at $f=1 \mathrm{~Hz}$.

We obtained the inter-annual trend by performing IFFT on the $0-0.7 \mathrm{~Hz}$ frequency range (Figure 7 ). A weak in
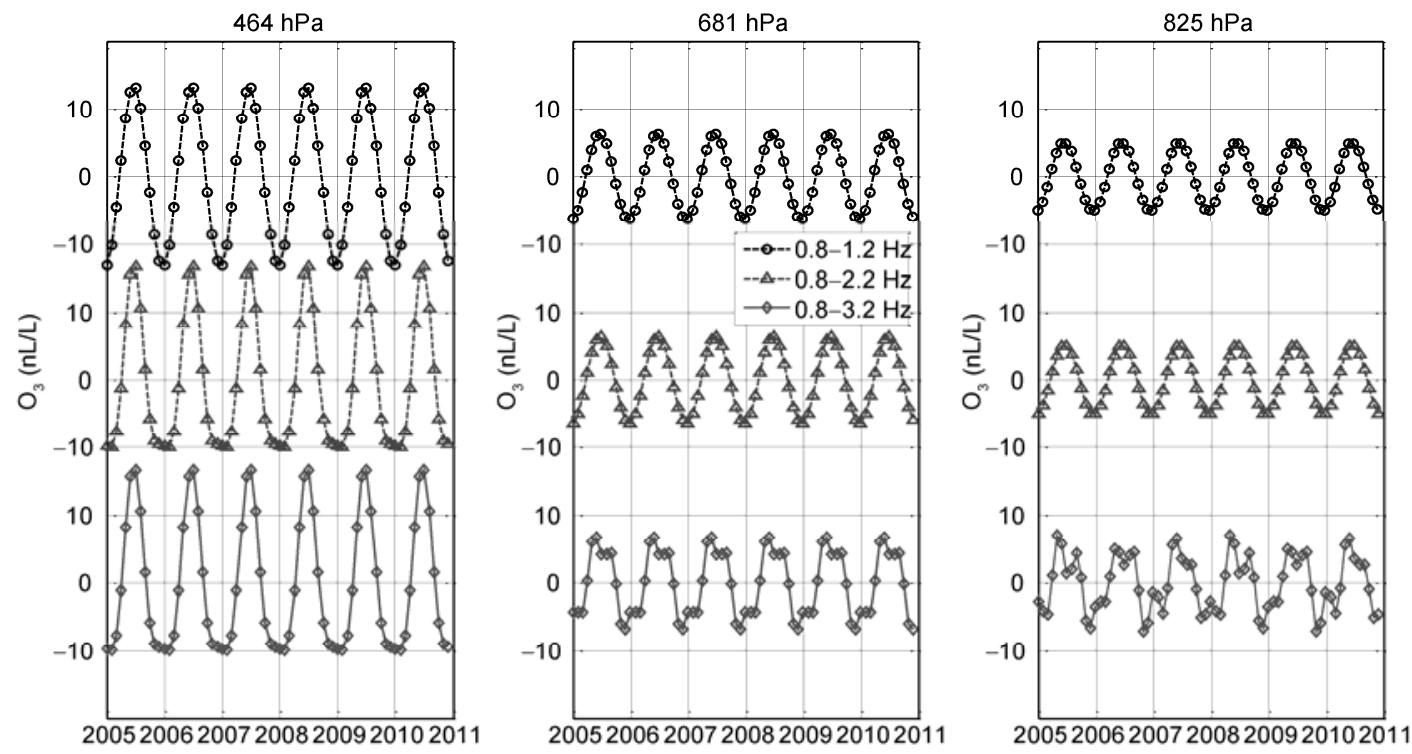

Figure 5 Seasonal variations of tropospheric ozone over northern China.
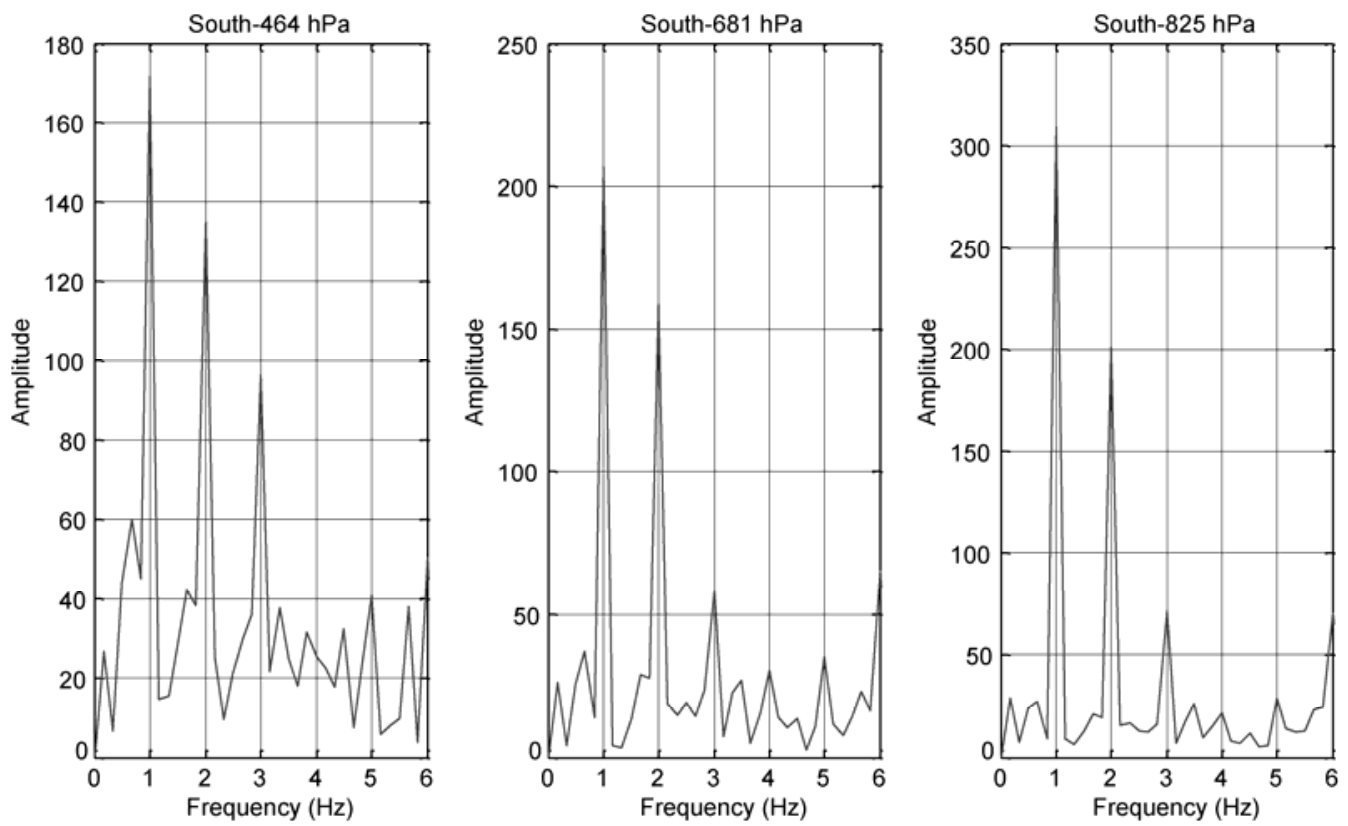

Figure 6 Frequency spectra of ozone over southern China at different pressure levels. 


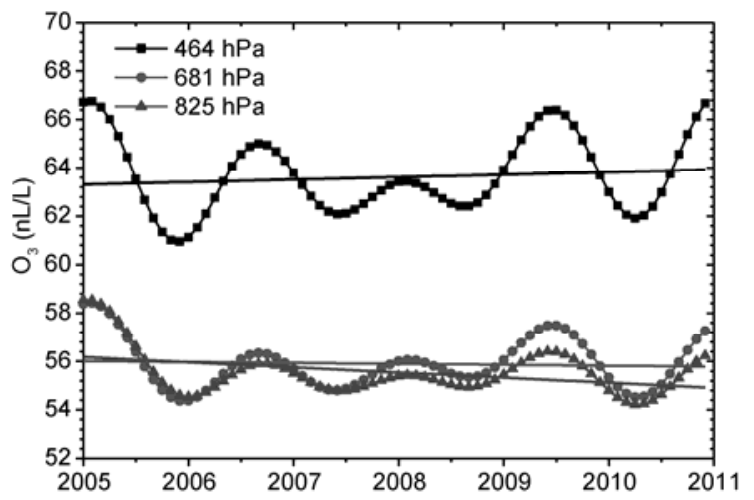

Figure 7 Inter-annual ozone trend over southern China.

creasing trend $(0.10 \pm 0.11 \mathrm{~nL} /(\mathrm{L} \mathrm{a}))$ is observed at $464 \mathrm{hPa}$ and a weak decreasing trend $(-0.21 \pm 0.061 \mathrm{~nL} /(\mathrm{L}$ a) $)$ is observed at $825 \mathrm{hPa}$. At $681 \mathrm{hPa}$, ozone concentrations remain constant over the five years $(-0.04 \pm 0.07 \mathrm{~nL} /(\mathrm{L} \mathrm{a}))$. This is consistent with the results of previous work which also showed a slight decreasing trend from 1991 to 2006 in Lin'an [22].

The frequency spectra shows that the ozone seasonal variation is 3 different cycles superimposed. By filtering out signals with amplitudes $<15 \%$ of the maximum amplitude, and performing IFFT on different frequency ranges including $0.8-1.2,0.8-2.2$ and $0.8-3.2 \mathrm{~Hz}$, Figure 8 show that the seasonal variations over southern China are more complex than those over northern China. A double-peaks phenomenon is significant at all three levels and $\mathrm{O}_{3}$ displays a summer minimum. The amplitude of the seasonal change is highest at $825 \mathrm{hPa}$, reaching -15 to $10 \mathrm{~nL} / \mathrm{L}$.

\subsection{Western China}

The frequency spectra of tropospheric ozone over western China appears in Figure 9. A strong signal appears at $f=1 \mathrm{~Hz}$ and a slightly weaker one at $f=2 \mathrm{~Hz}$ at $464 \mathrm{hPa}$.

The inter-annual trend was obtained by performing IFFT on the $0-0.7 \mathrm{~Hz}$ signals (Figure 10). An increasing trend $(+0.26 \pm 0.049 \mathrm{~nL} /(\mathrm{L} \mathrm{a})$ at $464 \mathrm{hPa}$ and $0.41 \pm 0.041 \mathrm{~nL} /(\mathrm{L} \mathrm{a})$ at $681 \mathrm{hPa}$ ) was observed over western China.

Over western China, the seasonal change of tropospheric ozone is very regular, with summer maxima and winter minima, (Figure 11). This regularity can be explained by the dominant role of the ozone background over this region and the very small anthropogenic influence. At $464 \mathrm{hPa}$ the amplitude reaches -10 to $12 \mathrm{~nL} / \mathrm{L}$, and is smaller at $681 \mathrm{hPa}$, reaching -5 to $5 \mathrm{~nL} / \mathrm{L}$.

\section{Conclusions}

The inter-annual trend and seasonal variations retrievedfrom TES over different regions in China is summarized in Table 2. Over the three regions, ozone mixing ratios are generally higher in summer and lower in winter. Over southern China at all three pressure levels and northern China at $825 \mathrm{hPa}$, however, ozone shows double peaks occurring in spring and autumn as a result of the combined effects of atmospheric chemistry and global transport [23]. Significant increases in ozone are found over all three regions at $464 \mathrm{hPa}$ and the rate of increase is fastest over northern China, reaching $0.89 \pm 0.059 \mathrm{~nL} /(\mathrm{L} \mathrm{a})$. At $681 \mathrm{hPa}$, ozone shows increases over northern and western China, at a rate of $0.57 \pm 0.065 \mathrm{~nL} /(\mathrm{L}$ a)
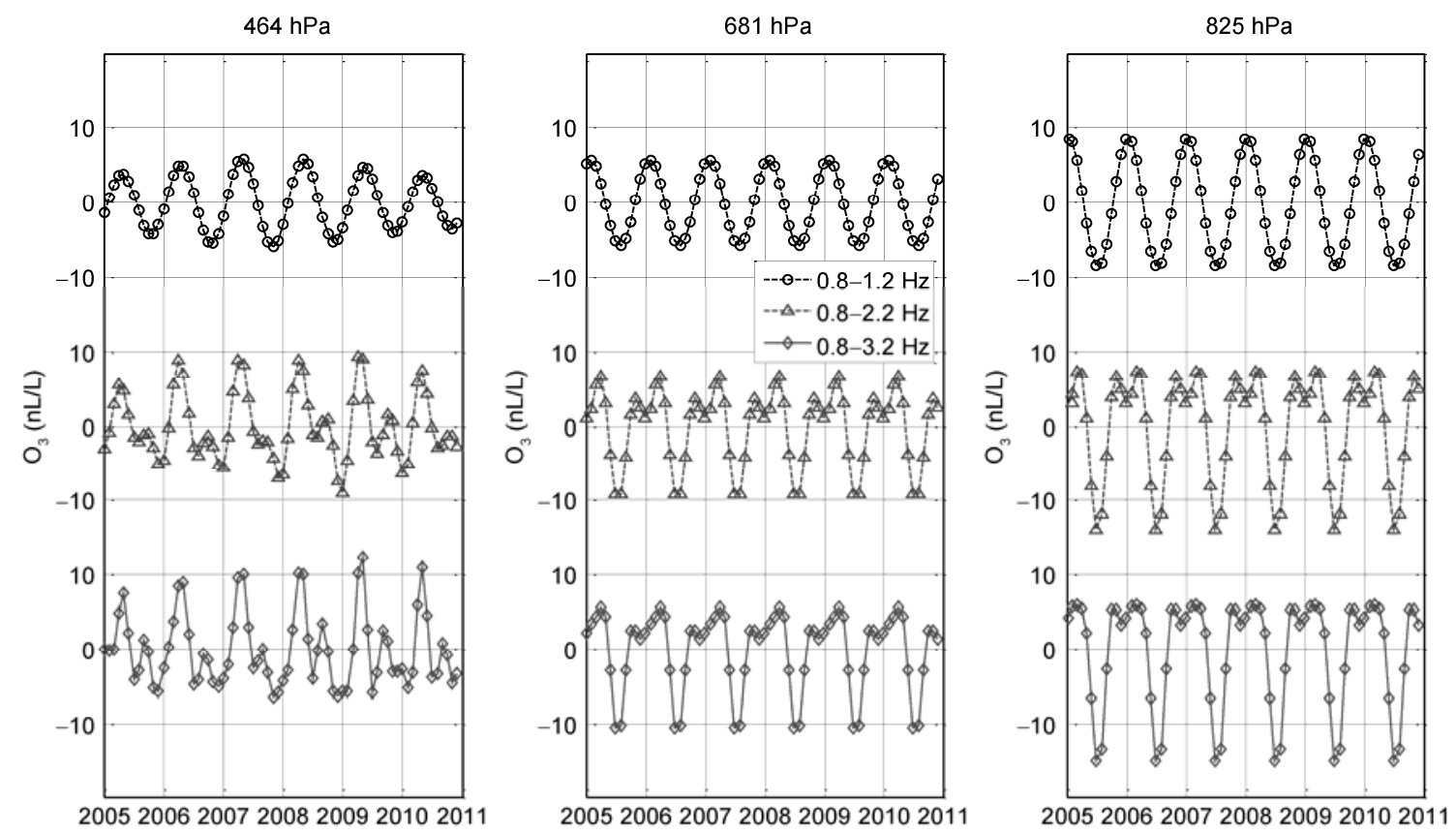

Figure 8 Seasonal variations of tropospheric ozone over southern China. 
Table 2 The summary of the inter-annual trend and seasonal variations of ozone in China from 2005 to 2010

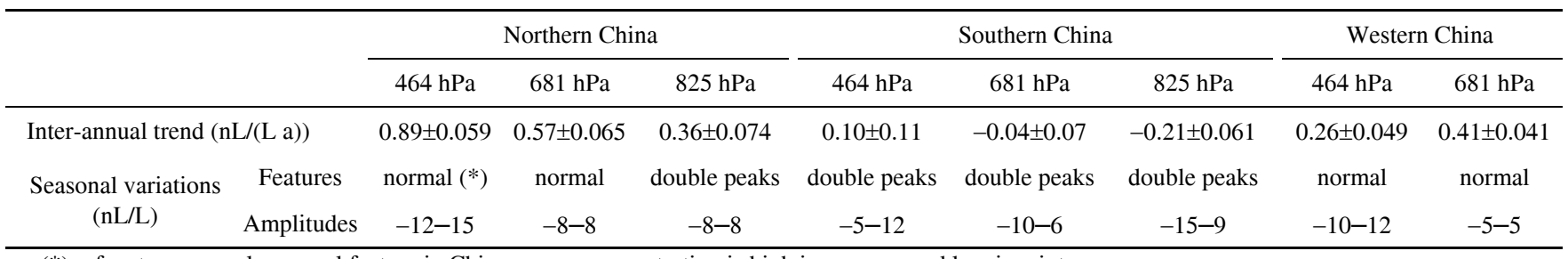

$(*)$ refers to a general seasonal feature in China: ozone concentration is high in summer and low in winter.
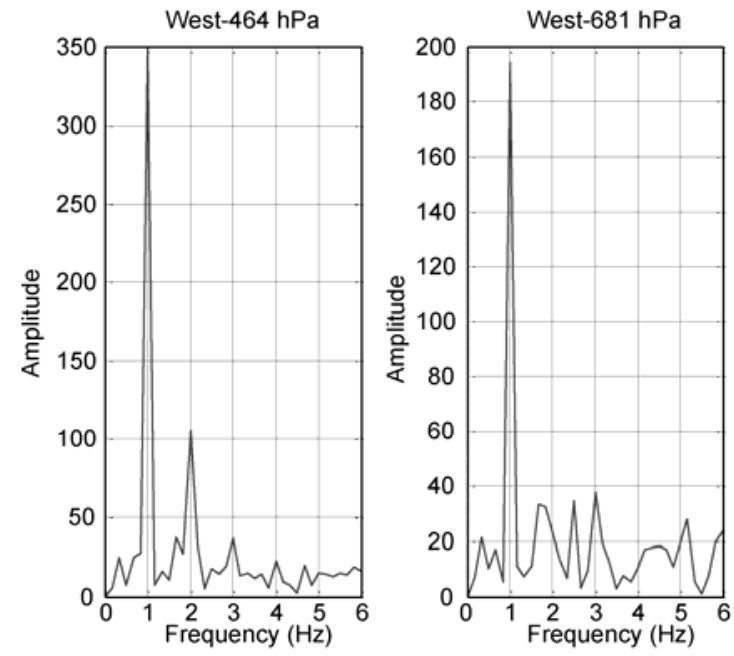

Figure 9 Frequency spectra of ozone over western China at various pressure levels.

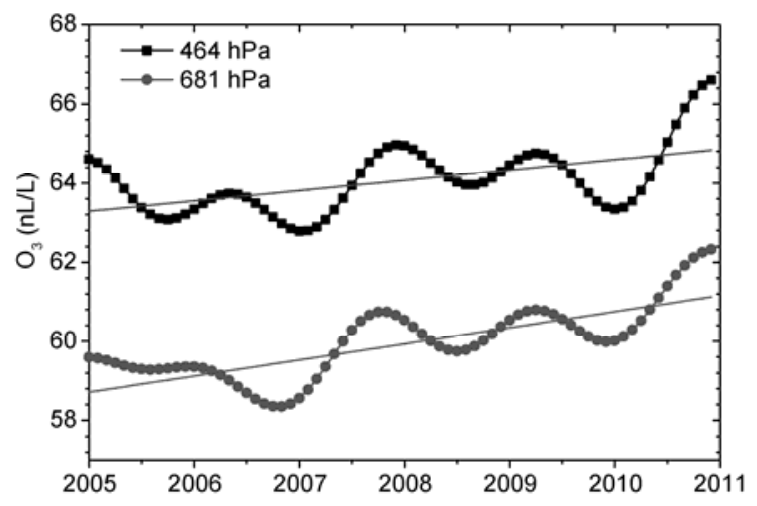

Figure 10 Inter-annual ozone trend over western China.

and $0.41 \pm 0.041 \mathrm{~nL} /(\mathrm{L}$ a) respectively, but is almost constant over southern China. At $825 \mathrm{hPa}$, ozone increases at a rate of $0.36 \pm 0.074 \mathrm{~nL} /(\mathrm{L}$ a) over northern China, while decreasing over southern China at a rate of $-0.21 \pm 0.061$ $\mathrm{nL} /(\mathrm{L}$ a) .

The TES data show an overall increase in tropospheric ozone concentrations over China from 2005 to 2010, implying increasing adverse impact of tropospheric ozone on human health, agricultural activity and eco-systems. Multiple factors may contribute to this increasing trend. One
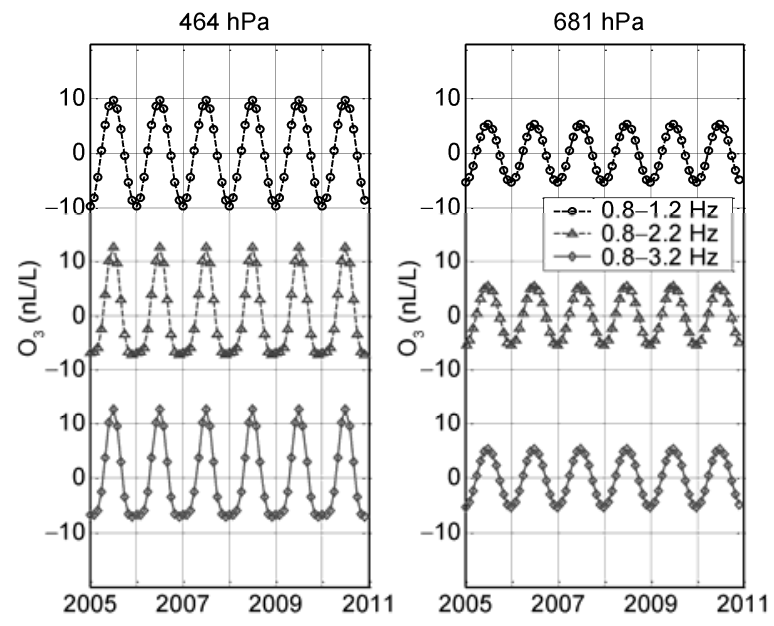

Figure 11 Seasonal variations of tropospheric ozone over western China.

reason is the rising emissions of ozone precursors, mostly over northern China. Another reason is the impact from the change in transport, including the stratosphere-troposphere ozone exchange over western China, and the monsoonal circulation in southern regions. Other natural factors, such as the climate-driven changes of soil $\mathrm{NO}_{x}$ emissions and biogenic VOCs emissions, can also contribute to the trend. This analysis provides a useful observational dataset and tools for future investigations into the mechanisms responsible for tropospheric ozone changes over China.

This work was supported by the National Natural Science Foundation of China (41005060). TES data is managed by NASA Jet Propulsion Laboratory (JPL) and we thank Dr. M. Luo at JPL for providing the TES ozone data.

1 Seinfeld J H, Pandis S N. Atmospheric Chemistry and Physics, from Air Pollution to Climate Change. New York: Wiley-Interscience Publication, 1998. 35-36

2 Wu S L, Mickley L, Leibensperger E M, et al. Effects of 2000-2050 global change on ozone air quality in the United States. J Geophys Res, 2008, 113: D06302

3 Akimoto H. Global air quality and pollution. Science, 2003, 302: 1716-1719

4 Fiore A M, Dentener F J, Wild O. Multi-model estimates of intercontinental source-receptor relationships for ozone pollution. J Geophys Res, 2009, 114, doi:10.1029/2008JD010816

5 Tang X Y, Zhang Y H, Shao M. Atmospheric Environmental Chemistry (in Chinese). Beijing: Higher Education Press, 2006.107-108 
6 Richter A, Burrows J P, Nuß H, et al. Increase in tropospheric nitrogen dioxide levels over China observed from space. Nature, 2005, 437: 129-132

7 Zhang L, Jacob D J, Boersma K F. Transpacific transport of ozone pollution and the effect of recent Asian emission increases on air quality in North America: An integrated analysis using satellite, aircraft, ozonesonde, and surface observations. Atmos Chem Phys, 2008, 8: 6117-6136

8 Ding A J, Wang T, Thouret V. Tropospheric ozone climatology over Beijing: Analysis of aircraft data from the MOZAIC program. Atmos Chem Phys, 2008, 8: 1-13

9 Wang T, Wei X L, Ding A J, et al. Increasing surface ozone concentrations in the background atmosphere of Southern China, 1994-2007. Atmos Chem Phys, 2009, 9: 6217-6227

10 Zhou X J, Luo C, Ding G A, et al. The ozone and its precursors concentration change in Eastern China (in Chinese). Sci China B, 1994, 24: $1323-1330$

11 Ding G A, Xu X B, Luo C, et al. Surface ozone characteristics at different areas under atmospherical background conditions in China (in Chinese). Acta Meteorol Sin, 2001, 59: 88-96

12 Zhu B, Wang T, Ni D H. Photochemical ozone and characteristics of its precursors in the boundary layer of Lin'an, a rural-agricultural site of Eastern China during 1999 autumn (in Chinese). J Nanjing Instit Meteorol, 2004, 27: 185-192

13 Liu J, Zhang X L, Zhang X C, et al. Surface ozone characteristics and the correlated factors at Shangdianzi atmospheric background monitoring station (in Chinese). Res Environ Sci, 2006, 19: 19-25

14 Boersma K F, Jacob D J, Bucsela E J, et al. Validation of OMI tropospheric NO2 observations during INTEX-B and application to con- strain $\mathrm{NO}_{x}$ emissions over the eastern United States and Mexico. Atmos Environ, 2008, 42: 480-497

15 Logan J A, Megretskaia I A, Nassar R, et al. Effects of the $2006 \mathrm{El}$ Nino on tropospheric composition as revealed by data from the Tropospheric Emission Spectrometer (TES). Geophys Res Lett, 2008, 35: L03816

16 Beer R. TES on the Aura mission: Scientific objectives, measurements, and analysis overview. IEEE Trans Geosci Remote Sens, 2006 , 44: 1102-1105

17 Bowman K W, Rodgers C D, Kulawik S S, et al. Tropospheric emission spectrometer: Retrieval method and error analysis. IEEE Trans Geosci Remote Sens, 2006, 44: 1297-1307

18 Nassar R, Logan J A, Worden H M, et al. Validation of tropospheric emission spectrometer (TES) nadir ozone profiles using ozonesonde measurements. J Geophys Res, 2008, 113: D15S17

19 Wang Y X, Munger J W, Xu S C, et al. $\mathrm{CO}_{2}$ and its correlation with $\mathrm{CO}$ at a rural site near Beijing: Implications for combustion efficiency in China. Atmos Chem Phys, 2010, 10: 8881-8897

20 Thoning K W, Tans P P, Komhyr W D. Atmospheric carbon dioxide at Mauna Loa observatory 2: Analysis of the NOAA GMCC data, 1974-1985. J Geophys Res, 1989, 94: 8549-8565

21 Tang G, Li X, Wang Y, et al. Surface ozone trend details and interpretations in Beijing, 2001-2006. Atmos Chem Phys, 2009, 9: 8813- 8823

$22 \mathrm{Xu} \mathrm{X}$, Lin W, Wang T, et al. Long-term trend of surface ozone at a regional background station in eastern China 1991-2006: Enhanced variability. Atmos Chem Phys, 2008, 8: 2595-2607

23 Wang Y X, Zhang Y Q, Luo M. Seasonal and spatial variability of surface ozone over China: Contributions from background and domestic pollution. Atmos Chem Phys, 2011, 11: 3511-3521

Open Access This article is distributed under the terms of the Creative Commons Attribution License which permits any use, distribution, and reproduction in any medium, provided the original author(s) and source are credited. 